\title{
Comparative Performance of Burnt Clay Bricks and Compressed Stabilized Earth Bricks and Blocks
}

\author{
C. Jayasinghe
}

\begin{abstract}
The prevailing shortage of many building materials based on natural resources has led to a considerable price escalation in recent times. This has created opportunities for developing many alternative masonry materials that can be used for wall construction. Compressed stabilised earth bricks, solid blocks and interlocking blocks are few such materials. To reduce the number of bricks used in a given area, Rat-trap bond is also gaining popularity. All these will create many challenges to the professionals involved in the building industry that have to be solved by providing data on strength and behaviour characteristics. This research compares the strength, load deformation characteristics and the applications of English and Rat-trap bond patterns in masonry construction. The findings are based on burnt clay bricks and compressed stabilized earth bricks and blocks in order to investigate comparableperformance.
\end{abstract}

Keywords: Compressed stabilized earth blocks (CSEB), bond patterns

\section{Introduction}

Masonry construction is very common in the housing industry all over the world. It has many advantages such as a single element fulfilling several functions including structure, fire protection, thermal and sound insulations, weather protection and sub-division of space while having high durability that allows long years of service.

Different masonry materials have been used in the Sri Lankan housing sector giving more prominence to burnt clay bricks and cement sand blocks in the recent past [1]. However, the shortage of raw materials available in Sri Lanka led to the development of many alternatives that can be used as walling materials. Such alternatives have been further promoted with the introduction of sustainable construction concepts. This paper covers two varieties of burnt clay bricks and different types of compressed earth blocks used as masonry units. The structural performance of such units has been assessed with strength parameters. The focus was also placed on different masonry bond patterns with the selected units and the structural performance which was assessed by testing wall panels.

When alternative masonry materials are considered, two materials have gained popularity in the recent time among house builders. They are compressed stabilized earth bricks and interlocking blocks. These bricks can be manufactured to the standard brick size of $215 \mathrm{~mm}$ x $105 \mathrm{~mm}$ x $65 \mathrm{~mm}$. The blocks can be manufactured as solid or interlocking. The thickness of a block can vary from $140 \mathrm{~mm}$ to $240 \mathrm{~mm}$. When the burnt clay bricks are considered, the sizes and quality of bricks available in the market vary to some extent. Thus, the alternative masonry materials and manufacturing methods have introduced an added complexity to the use of masonry for house construction. These can give many variations that are generally not covered in BS 5628: Part 1: 1992 [2]. Thus, for effective use of such masonry, it is very important to have data on the performance. The research presented in this paper provides the strength parameters based on laboratory testing of wall panels. The practical applications of such data are discussed with respect to typical features of single and two storey houses constructed in Sri Lanka.

\section{Objectives}

The main objectives are the following:

a. Determination of the strength characteristics of different masonry units consisting of burnt clay bricks, stabilized earth bricks and blocks and the corresponding wall strengths.

b. Determination of comparative performance of different bond types.

Eng. (Dr.)Mrs.C.Jayasinghe, C. Eng., MIE(SL), B.Sc. Eng. (Hons) (Moratuwa), M.Eng, PhD, Senior Lecturer; Department of Civil Engineering, Universitvof Moratuwa, Sri Lanka. 
c. Investigation of suitable applications for above masonry units.

\section{Methodology}

The following methodology was used:

a. The different masonry units were used for constructing wall panels with different bond patterns.

b. The strength and load deformation behaviour were obtained with laboratory testing.

c. The applications of different types of masonry were investigated with respect to the typical features of single and two storey houses.

d. Recommendations were developed for applications.

\section{Masonry units selected for the study}

\subsection{Burnt clay bricks}

The bricks of standard size of $215 \mathrm{~mm}$ x $105 \mathrm{~mm}$ x $65 \mathrm{~mm}$ were used for one of the testing series. Only few manufacturers are currently manufacturing these standard bricks in Sri Lanka. They are identified as burnt clay Type 1 for further discussion. A sample was physically tested to check whether it complies with the recommended testing such as impact test, ringing sound etc [3]. Another set of locally available non standard bricks was selected for comparison purposes (identified as burnt clay brick Type 2 for further discussion) which was selected by testing the brick for physical testing such as impact test and ringing sound test. These bricks are generally manufactured as a cottage industry and hence readily available. The size is about $200 \mathrm{~mm}$ length $\mathrm{x} 100 \mathrm{~mm}$ width $\mathrm{x} 50 \mathrm{~mm}$ height. Both types of bricks were used in the experimental programme to investigate their behaviour under vertical loading. The unit strengths of both types of bricks are given in Table 1.

\subsection{Compressed stabilised earth bricks and blocks}

It is possible to manufacture bricks and blocks using cement stabilised earth. At least 5\% cement is recommended for stabilization $[4,5]$. The clay and silt content of less than $35 \%$ gives good strength with compaction ratio in excess of 1.65. $[4,6,7]$. Compaction ratio is the height of soil prior to compacting to height of the finished block. The main raw material used to manufacture CSE bricks and blocks is laterite soil which is commonly available in Sri Lanka. A comprehensive study done by Kasthurba et. al

Table 1: Average wall strengths

\begin{tabular}{|c|c|c|c|c|c|c|}
\hline Unit & $\begin{array}{l}\text { Bond } \\
\text { pattern }\end{array}$ & $\begin{array}{c}\text { Unit } \\
\text { strength } \\
\left(\mathrm{N} / \mathrm{mm}^{2}\right)\end{array}$ & $\begin{array}{c}\text { Stress at } \\
\text { first crack } \\
\mathrm{N} / \mathbf{m m}^{2}\end{array}$ & $\begin{array}{l}\text { Ultimate } \\
\text { compressive } \\
\text { strength } \\
\mathrm{N} / \mathbf{m m}^{2}\end{array}$ & $\begin{array}{l}\text { Average } \\
\text { ultimate } \\
\text { strength } \\
\mathbf{N} / \mathbf{m m}^{2}\end{array}$ & $\begin{array}{l}\text { Wall } \\
\text { thickness } \\
\quad(\mathrm{mm})\end{array}$ \\
\hline $\begin{array}{l}\text { Burnt clay } \\
\text { brick (Type 1) }\end{array}$ & English & 8.30 & $\begin{array}{l}1.20 \\
1.22\end{array}$ & $\begin{array}{l}3.11 \\
3.07\end{array}$ & 3.09 & 225 \\
\hline $\begin{array}{l}\text { Burnt clay } \\
\text { brick (Type 1) }\end{array}$ & Rat-trap & 8.30 & $\begin{array}{r}0.35 \\
0.322\end{array}$ & $\begin{array}{l}1.77 \\
1.53\end{array}$ & 1.65 & 225 \\
\hline $\begin{array}{l}\text { Burnt clay } \\
\text { brick (Type 2) }\end{array}$ & English & 2.50 & $\begin{array}{l}1.19 \\
0.45\end{array}$ & $\begin{array}{l}1.58 \\
2.15\end{array}$ & 1.87 & 210 \\
\hline $\begin{array}{l}\text { Burntclay } \\
\text { brick ( Type 2) }\end{array}$ & Rat-trap & 2.50 & $\begin{array}{l}0.45 \\
0.52 \\
\end{array}$ & $\begin{array}{l}1.09 \\
0.86\end{array}$ & 0.975 & 198 \\
\hline CSE brick & English & 5.40 & $\begin{array}{l}1.10 \\
0.75 \\
\end{array}$ & $\begin{array}{l}2.62 \\
2.49\end{array}$ & 2.56 & 225 \\
\hline CSE brick & Rat-trap & 5.40 & $\begin{array}{l}1.26 \\
0.65\end{array}$ & $\begin{array}{l}1.92 \\
1.63\end{array}$ & 1.78 & 227 \\
\hline $\begin{array}{l}\text { CSE (Type 1) } \\
\text { Interlocking }\end{array}$ & Stretcher & 4.40 & $\begin{array}{l}0.95 \\
0.90\end{array}$ & $\begin{array}{l}1.20 \\
1.30\end{array}$ & 1.25 & 235 \\
\hline $\begin{array}{l}\text { CSE (Type 2) } \\
\text { Interlocking }\end{array}$ & Stretcher & 5.35 & $\begin{array}{l}0.63 \\
0.63 \\
\end{array}$ & $\begin{array}{l}1.71 \\
1.98\end{array}$ & 1.845 & 145 \\
\hline $\begin{array}{l}\text { CSE (Type 3) } \\
\text { plain solid }\end{array}$ & Stretcher & 5.50 & $\begin{array}{l}2.50 \\
2.25\end{array}$ & $\begin{array}{l}3.19 \\
3.00\end{array}$ & 3.095 & 235 \\
\hline
\end{tabular}


[8] has elaborated the main constituent materials in lateritic soils and the pozzolanic reactions occurring when used as a raw material for stabilized earth blocks. Laterite soil can give better results than that with any other soil type.

Three different types of units have been investigated in this study. They are the CSE bricks manufactured to the standard brick size as shown in Figure 1 mainly using suitable laterite soils with a hydraulic press that can give a compaction ratio of 1.8. The solid CSE interlocking blocks (Type 1) of size of $235 \mathrm{~mm} \mathrm{x}$ $235 \mathrm{~mm} \times 140 \mathrm{~mm}$ height were also used in the experimental programme. They have grooves to ensure interlocking (solid interlocking) of the blocks as shown in Figure 1. They can be manufactured as solid blocks without interlocking as well as shown in Figure 1. This type is not considered in this study since previous studies have covered this type with detailed testing programmes [4].

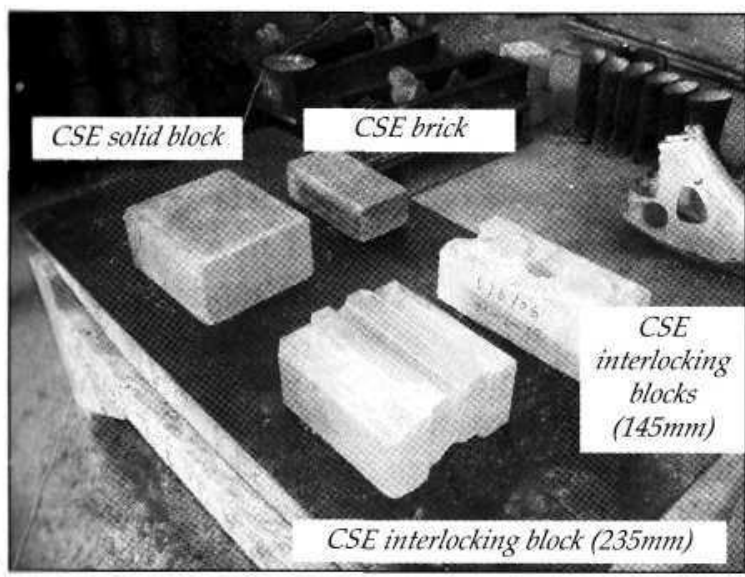

Figure 1 - Different CSE bricks and blocks used in the testing programme

The other is interlocking blocks (hollow interlocking), which has dimensions of $295 \mathrm{~mm}$ x $145 \mathrm{~mm}$ x $100 \mathrm{~mm}$ with holes of providing continuity, as shown in Figure 1. This is identified as CSE Type 2.

\section{Bond patterns}

The CSE bricks have wire cut finish. They can be used with English bond for one brick thick walls. Another bond type that is gradually gaining popularity is Rat-trap bond [9] which is indicated in Figure 2. Both these bond patterns were used for the experimental programme with one brick thick walls. In order to have a

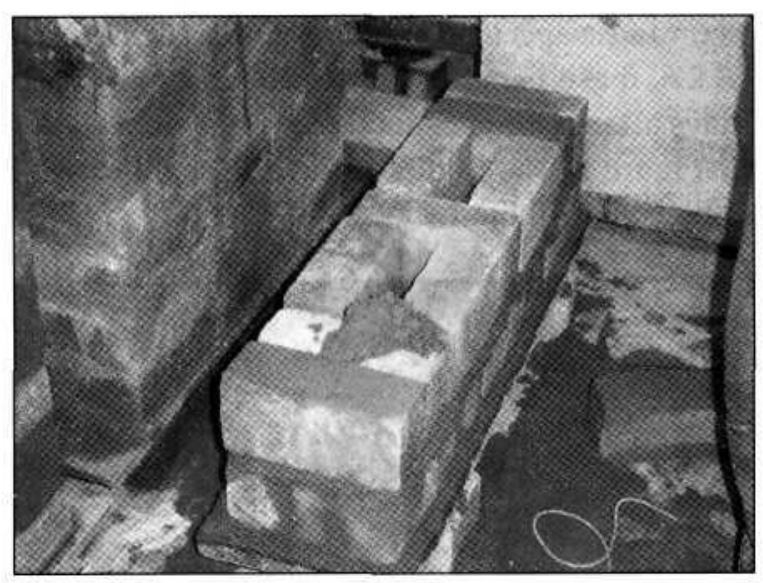

Figure 2 - Rat-trap bond under construction

comparison, locally manufactured standard and non- standard burnt clay bricks were used to construct wall panels with English bond, and Rat-trap bond to a thickness of one brick.

The interlocking solid block (Block Type 1) can be laid with mortar or pasted as interlocking with cement soil slurry (Figure 3) using a stretcher bond. The interlocking blocks with holes (Block Type 2) can be laid as interlocking with stretcher bond using cement soil slurry and then made continuous with a soil cement paste filled into the holes as shown in Figure 3. The block is $145 \mathrm{~mm}$ thick which becomes the thickness of the wall.

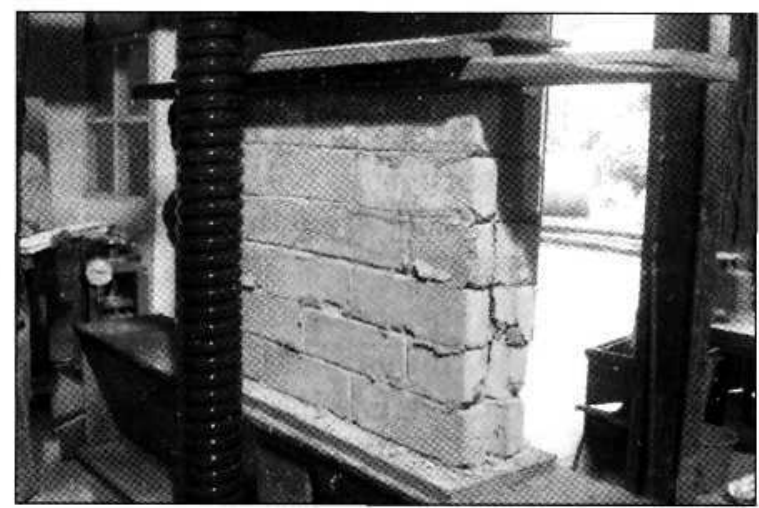

Figure 3 - Testing of a hollow interlocking panel bonded with cement soil slurry

\section{Wall strengths}

BS 5628: Part 1: 1992 [2] recommends the use of wall panel testing for the determination of wall strengths. For the comparative study conducted for brunt clay bricks and CSE bricks, one brick thick wall panels of three bricks length and six courses high were constructed. For each case, 2 panels were constructed using 1:5 cement sand 
mortar. As specified in BS 5628: Part 1: 1992, Cl. A.2.6, these panels were tested at an age of 28 days after casting, using the arrangement shown in Figure 4. The results of the brick panel testing are given in Table 1.

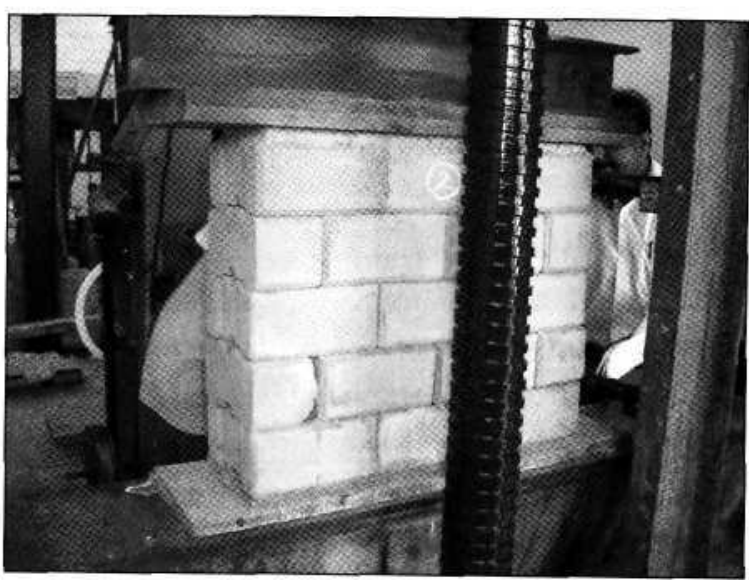

Figure 4 - Interlocking solid block panel ready for testing

For CSE Type 1 and 2 blocks, a panel size of three blocks of length and five courses of high was selected. They were also tested 28 days after casting. The results are also given in Table 1. The above results have been used to obtain the characteristic strength for brick and block walls as presented in Table 2. The characteristic strength was evaluated as average strength divided by 1.2 as recommended in BS 5628: Part 1: 1992 [2].

For each panel tested, a sample of 3 bricks or blocks was tested to determine the unit strength

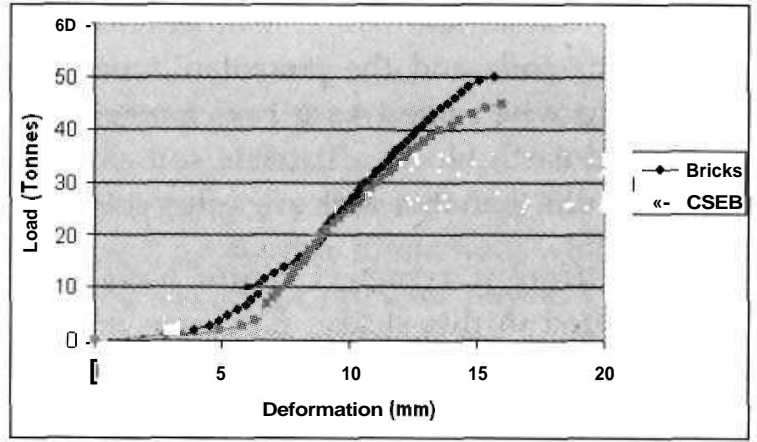

Chart 1 - Load deformation curves for the curves for the English bond with bricks and CSE bricks

of the material. All the bricks were tested under saturated surface dry conditions and the CSE bricks and blocks were tested both in ambient air dry condition and at saturated surface dry condition to determine the wet strength. All the CSE bricks and blocks have shown wet strength more than $0.5 x$ dry strength which is satisfactory according to the accepted standards $[10,11,12,13]$

Since CSE are produced in a greater variety of unit sizes, each block type was tested for compression even though they were produced using the same raw material. It is recommended that influence of unit geometry on performance needs to be accommodated in a reliable and consistent manner [14]. Therefore, all the interlocking blocks were capped with: 1:3 cement sand mortar and kept under ambient conditions for duration of two weeks prior to testing.

Table 2: Characteristic strength of wall panels

\begin{tabular}{|c|c|c|c|c|}
\hline Unit & Bond pattern & $\begin{array}{l}\text { Average ultimate } \\
\text { strength } \mathrm{N} / \mathrm{mm}^{2}\end{array}$ & $\begin{array}{c}\text { Characteristic } \\
\text { strength } \mathrm{N} / \mathrm{mm}^{2}\end{array}$ & $\begin{array}{l}\text { Wall thickness } \\
\qquad(\mathrm{mm})\end{array}$ \\
\hline $\begin{array}{l}\text { Burnt clay brick } \\
\text { (Type 1) }\end{array}$ & English & 3.09 & 2.58 & 225 \\
\hline $\begin{array}{l}\text { Burnt clay brick } \\
\text { (Typel) }\end{array}$ & Rat-trap & 1.65 & 1.38 & 225 \\
\hline $\begin{array}{l}\text { Burnt clay brick } \\
\text { (Type 2) }\end{array}$ & English & 1.87 & 1.55 & 210 \\
\hline $\begin{array}{l}\text { Burnt clay brick } \\
\text { (Type2) }\end{array}$ & Rat-trap & 0.975 & 0.813 & 198 \\
\hline CSE brick & English & 2.56 & 2.13 & 225 \\
\hline CSE brick & Rat-trap & - 1.78 & 1.48 & 227 \\
\hline $\begin{array}{l}\text { CSE (Type 1) } \\
\text { Interlocking }\end{array}$ & Stretcher & 1.25 & 1.04 & 235 \\
\hline $\begin{array}{l}\text { CSE (Type 2) } \\
\text { Interlocking }\end{array}$ & Stretcher & 1.845 & 1.54 & 145 \\
\hline $\begin{array}{l}\text { CSE (Type 3) } \\
\text { plain solid }\end{array}$ & Stretcher & 3.095 & 2.60 & 235 \\
\hline
\end{tabular}




\section{Load deformation behaviour}

Load deformation behaviour of masonry is important to judge whether adequate warning is given by the wall before failure. This was studied for all the test panels by fixing dial gauges at the top and bottom levels to check the vertical deformations at each loading step. Chart 1 shows the load deformation curves for burnt bricks and CSE bricks where the bond pattern was English. Both these materials show somewhat ductile behaviour with adequate warning before failure which is a satisfactory result for masonry walls. Wall panels constructed with English bond were able to carry additional loads after the formation of cracks. This is a good indication that the wall will be able to give adequate warning prior to ultimate loads. The load versus deformation curve also indicates a curved portion prior to ultimate loads.

The Rat-trap bond developed severe cracks accompanied by a sound that indicated breaking of the header bricks that provided the link between the two leaves formed by bricks on edge. The warning given was less when compared with that for the English bond.

\section{Applications for the above masonry units and bond patterns}

The majority of houses constructed in Sri Lanka consist of single or two storey. For two storey houses, economy is achieved by using load bearing masonry. It is possible to identify a few distinct features for these houses.

a. Small single storey house with cement fibre sheet roof with low angles $\left(10^{\circ}-12^{0}\right)$ where the maximum wall height would be limited to $4.0 \mathrm{~m}$.

b. Large single storey houses with cement fibre sheet roof with low angle where the maximum wall heights would be $5.0 \mathrm{~m}$ or more due to the considerable length of the roof.

c. Houses with clay or micro concrete tiles with roof angles of $22^{\circ}$ or more which will need wall heights of about $5.0 \mathrm{~m}$ or more.

d. Two storey houses where the ground floor height is $2.7 \mathrm{~m}$. The upper floor is similar to a single storey house where the wall height varies with different roofing angles.

For masonry construction, the required strength is determined by the loads and the slenderness effects. In single storey houses, the stresses due to loads are low and the self weight induced stresses will dominate. However, the height can become a governing factor for the thickness of the walls since the slenderness ratio has to be limited to 27 according to BS 5628: Part 1: 1992 [2].

When the restraints offered by the roof and the ceiling frames are considered, it is possible to consider the effective height as $0.75 \mathrm{x}$ the clear height. This is assuming enhanced resistance to lateral movement as specified in $\mathrm{Cl}$ 28.2.2 of BS 5628: Part 1: 1992 [2]. It is also possible to provide additional restraint by using a continuous lintel above the door and window openings, which will ensure that the use of 0.75 $\mathrm{x}$ the clear height is clearly justifiable. Thus, for a $4.0 \mathrm{~m}$ high wall, the effective height is $3.0 \mathrm{~m}$. For a wall thickness of $105 \mathrm{~mm}$ as can be obtained with standard half brick walls, the slenderness is $3000 / 105,>27$. Thus the use of half brick thick walls will not be desirable unless continuous lintels are used that can offer additional restraints at the intermediate heights.

The design vertical load resistance of a wall depends on the characteristic strength, wall thickness, partial safety factors and the capacity reduction factor $(\beta)$ which allows for the effects of slenderness and eccentricity of loads. With $145 \mathrm{~mm}$ thick walls, for a height of $4.0 \mathrm{~m}$, the slenderness ratio is $3000 / 145=20.6$. For this, the capacity reduction factor $(\beta)$ can vary from 0.33 to 0.66 , depending on the eccentricity of loads. Since the self weight dominates in single storey construction, ( 3 will be 0.66 . For $5.0 \mathrm{~m}$ high walls, slenderness ratio is $0.75 \times 5000 / 145$ $=25.8$. Thus for single storey houses with clay tiles or micro concrete tile roofing, the capacity reduction factor can be about 0.45 . This means $145 \mathrm{~mm}$ thick walls obtained with CSE Type 2 interlocking blocks may not be advisable if the wall heights are more than $5.0 \mathrm{~m}$.

The characteristic wall strengths are given in Table 2. The adequacy of wall strengths can be checked with partial factors of safety of 1.4 for dead loads and 1.6 for imposed load (an average value of 1.5). For masonry, it is recommended 
to consider the ultimate stresses and then to couple it with a sufficient factor of safety to ensure satisfactory behaviour under the service conditions [15]. Considering the reduction of strength in the wet state, a partial factor of safety for material strength of 3.5 can be recommended on the basis of normal manufacturing and construction control (as specified in BS 5628: Part 1: 1992)for CSE bricks and blocks although the production under factory conditions would warrant lower values. When these partial factors of safety are considered, an overall factor of safety $1.5 \times 3.5=5.25$ can be obtained.

All the above data will allow the carrying out of a structural design to check the adequacy of masonry. For example, if a $145 \mathrm{~mm}$ thick wall is used for a wall of height $5.0 \mathrm{~m}$ the stress at the plinth level will be about $0.12 \mathrm{~N} / \mathrm{mm}^{2}$ inclusive of roof loads. With an overall factor of safety of 5.25 and a capacity reduction factor of 0.45 the characteristic strength required will be $0.12 \times 5.25 / 0.45=1.4 \mathrm{~N} / \mathrm{mm}^{2}$. The characteristic strength obtained with the experimental programme as given in Table 2 is $1.54 \mathrm{~N} / \mathrm{mm}^{2}$. This indicates the validity of restrictions proposed for various wall heights and block thicknesses in the conclusions.

For taller walls, it is advisable to use one brick thick walls. For one brick thick walls, it is possible to use either English or Rat-trap bond. The advantage of Rat-trap bond is that it achieves the higher wall thickness with a lesser number of bricks. For this, either standard size burnt clay bricks or CSE bricks can be used. Even for a wall height of $6.0 \mathrm{~m}$, it is possible to keep the slenderness ratio at $0.75 \times 6000 / 225=$ 20 for a restrained wall. This gives a capacity reduction factor of 0.7 . The service stress will be about $0.14 \mathrm{~N} / \mathrm{mm}^{2}$. The corresponding design stresses will be $0.14 \times 5.25 / 0.7=1.05 \mathrm{~N} / \mathrm{mm}^{2}$. The characteristic strength values given in Table 2 indicate that both English and Rat-Trap bonds can provide adequate strength with standard size brunt clay or CSE bricks. The use of Rattrap bond with non standard bricks should be given careful consideration since the characteristic wall panel strength was only about $0.8 \mathrm{~N} / \mathrm{mm}^{2}$.

Alternatively, the solid block of $235 \mathrm{~mm}$ thickness can be used either as interlocking or with mortar for such wall heights. In the context with present shortage of sand, the use of the block as interlocking will have distinct advantages when used for house construction. The failure of interlocking block masonry is generally due to the development of shear stresses at the interlocking webs in addition to the vertical cracks in the block shells developed with increased load [16]. This can be attributed to the relatively low characteristic strengths obtained with interlocking solid blocks of 235 $\mathrm{mm}$ thickness in Table 2, which is $1.04 \mathrm{~N} / \mathrm{mm}^{2}$.

For the ground floor of a two storey house, the slenderness effects would be of less significance. The concrete slab can provide good restraint to the wall. The wall height is low due to the presence of the floor slab. The building regulations indicate a minimum height of $2.7 \mathrm{~m}$ [17]. Thus, for one brick thick walls, the slenderness ratio will be as low as $0.75 \times 2700$ / $225=9$. However, due to load bearing construction, the stresses will be high. Thus, a wall characteristic strength of at least $1.5 \mathrm{~N} /$ $\mathrm{mm}^{2}$ is recommended [3]. The walls with both burnt clay and CSE bricks can achieve this with English bond. Even though Rat-trap bond with standard brick sizes also achieves sufficient strength, it may be advisable not to use it when heavy loads are expected considering the fact that its strength may depend on the quality of brick laying to a greater extent than the solid walls laid with mortar. Thus, the use of Rat-trap bond for the ground floor load bearing walls of a two storey house even with standard size bricks is not encouraged. However, Rat-trap bond pattern has other advantages like optimum material usage, relatively high indoor thermal comfort, etc. Therefore, if Rat-trap bond is selected for the ground floor of a two storey construction, strengthening should be done with reinforced concrete frame work at the places where high stress concentrations occur. Alternatively, Rat-trap bond could be economically used for the infill panels when the reinforced concrete frame is used.

The contents of above discussion can be summarized as follows:

a. For small single storey houses with cement fibre sheeted roof with wall heights limited to $4.0 \mathrm{~m}$, a wall thickness of $145 \mathrm{~mm}$ given by interlocking blocks can be used.

b. For large single storey houses with wall heights up to $5.0 \mathrm{~m}$, it is advisable to use 
standard burnt clay or CSE bricks with one brick thick walls with either English bond or Rat-trap bond even up to a wall height of $6.0 \mathrm{~m}$.

c. The use of non standard bricks with Rat-trap bond should be given careful consideration since the strength may not be sufficient.

d. It also possible to use $235 \mathrm{~mm}$ thick solid or interlocking CSE blocks for such tall walls.

e. For two storey houses, bunt clay or CSE bricks can be used with English bond to act as a load bearing material. The use of Rattrap bond should be coupled with a reinforced concrete frame at the ground floor. The use of $235 \mathrm{~mm}$ thick CSE solid block laid with mortar also can provide adequate strength for loadbearing walls of two storey houses.

\section{Cost Aspects}

A cost study is important to compare the cost of various types of masonry walls possible with burnt clay bricks and cement stabilized earth bricks and blocks. A distinct advantage of machine cast bricks and blocks is the ability to provide an attractive appearance without plasters. Thus, for cost comparison, the situations resulting with and without plaster could be considered. When the wall panels were constructed using different bond patterns, the number of bricks used was recorded and a cost evaluation was done considering the number of units used per one square metre of the wall and the number of mortar joints.

When different bond patterns were compared, it was found that with the standard bricks, there is a saving of $20 \%$ of units with the Rat-trap bond compared to the English bond whereas it is $28 \%$ when using non standard bricks. When the CSE bricks are used, the saving is in the range of $15 \%$ when the Rat-trap bond is used.

When CSE bricks/blocks are used, there is about $20 \%-30 \%$ saving in the construction cost when compared with the burnt clay bricks mainly arising with the saving in the mortar needed for laying due to interlocking nature or larger unit size. This saving will further increase if the wall can be finished without a plaster. A detailed study on the costs will be presented in a future research paper considering the prevailing market rates of the building materials.

\section{Conclusions}

Different types of Compressed Stabilized Earth Blocks and Bricks can be used in wall construction in various ways including different bond patters. However, this creates many challenges to the professionals in the building industry, since they may be compelled to recommend masonry that is not strictly covered in the Standards. The detailed study presented in this paper has provided valuable strength data that can solve this problem.

It is shown that cement stabilised earth blocks of thickness $145 \mathrm{~mm}$, or in that range, can be used for wall heights up to $4.0 \mathrm{~m}$ without any restriction. The use of these for greater heights such as $5.0 \mathrm{~m}$, will need many extra precautions such as additional tie beams and return wall of full height to reduce the slenderness effects. Alternatively, thicker blocks such as interlocking or plain solid blocks of $235 \mathrm{~mm}$ thickness can be used.

The compressed stabilised earth bricks have indicated exceptionally good strengths with English bond. These bricks are suitable even for load bearing ground floor walls of two storey houses. They can be easily used up to $6.0 \mathrm{~m}$ tall restrained walls in single storey construction.

A bond of recent origin is the Rat-trap which can provide a useful solution when thicker walls are required in single storey houses to minimise the strength reductions associated with slenderness effects. These walls with standard size bricks can be used for restrained walls of up to $6.0 \mathrm{~m}$ height.

A Rat-trap bond may not be advisable for the ground floor of a two storey house with load bearing construction. However, it can be used as infill walls with a reinforced concrete frame construction.

This paper has clearly highlighted many different applications, with the constraints, for masonry resulting from bond patterns and the use of alternative materials. Further research and development work is going on in the areas of different bond patterns of compressed stabilised earth blocks in terms of flexural and 
shear resistance in order to withstand the lateral forces. These findings will be published in the near future. With all these results it would be possible to use CSEB as a masonry material with much confidence.

\section{Acknowledgements}

The author wishes to thank the Senate Research Committee of the University of Moratuwa, for providing funds for this research. The support given by the block manufacturers and the technical staff, Messers SP Madanayake, SL Kapuruge and HP Nandaweera of the Department of Civil Engineering, University of Moratuwa is gratefully acknowledged.

\section{References}

1. Census of Population and Housing -2001, www.statistics .gov.lk

2. BS 5628: PART 1: 1992, CODE OF PRACTICE FOR USE OF MASONRY, British Standards Institute, United Kingdom

3. JAYASINGHE, M. T. R., Load-bearing construction with local bricks, Engineer, Journal of Institution of Engineers, Sri Lanka, xxvii, (1), pp 49-57, 1998.

4. JAYASINGHE C., Alternative Building Materialand Methods for SriLanka, Ph.D. Thesis, Department of Civil Engineering, University of Moratuwa, Sri Lanka, 1999.

5. PERERA A.A.D.A.J. and JAYASINGHE C., Strength characteristics and structural design methods for compressed earth block walls, Masonry International, 16(1): 34-38, 2003;

6. BAHAR R, BENAZZOUNG $M$ and KENAI S., Performance of compacted cement stabilized soil, Cement \& Concrete composites, 26, 811-820, 2004.

7. WALKER P and MANIATIDIS V., A review of rammed earth construction, Natural Building Technology group, Department of Architecture and Civil Engineering, University of Bath, United Kingdom, 2003.

8. Kasthurba A.K., Santhanam M., Mathews M.S., Investigation of laterite stones for building purpose from Malabar region, Kerela State, SW India - Part I, Field studies and profile characterisation, Construction and Building Materials, 21, (2007), 73 -82

9. ARCHIFACTS, http://www.archifacts.co.uk/ html/ brickwork_paving_bond_patterns.htm.
10. NEW MEXICO EARTHEN BUILDING MATERIALCODE, 2003.

11. The Australian Building handbook, Standards Australia, Sydney, Australia, 2002.

12. NZS 4297: 1998, NEW ZEALAND STANDARDS, Engineering design of earth buildings, Standard New Zealand, Wellington, New Zealand

13. HEATHCOTE K.A., Durability of earth wall buildings, Construction and Building Materials, 9(3), 185-189, 1995

14. MOREL J.C., MESHAH A., OGGERO M. and WALKER P., Building houses with local material: means to drastically reduce the environmental impact of construction, Building and Environment;36, 1119-1126,2001.

15. HENRY A.W., Structural Masonry, Mac million Press, London, P 284, 1990,

16. Jaafar M.S., Thanoon W.A., Najm A. M. S. Abdulkadir M.R., Ali A.A.A., Strength correlation between individual block, prism and basic wall panel for load bearing interlocking mortorless hollow block masonry, Construction and Building Materials, 20, (2006), 492 -498.

17. City of Colombo Development Plan, Volume II 1999, Urban Development Authority, Ministry of Housing and Construction. 